\title{
KEKERASAN DALAM RUMAH TANGGA DAN UPAYA PENANGGULANGANNYA MELALUI PENDEKATAN INSTITUSI LOKAL DAN FORMAL
}

\author{
Silfia Hanani \\ Sekolah Tinggi Agama Islam Negeri (STAIN) Bukittinggi \\ Email: silfia_hanani@yahoo.com
}

\begin{abstract}
Abstrcat: Many factors influence the increasing of domestic violence. They are economics, cultural, the limitation of society knowledge about domestic violence, and the limitation of available formal institution as the place of termination of domestic violence cases. The limitation of the formal institution can be understood, because it relates to the formal problem which is arranged by state, so that, the formal institution cannot be expected fully becomes a place of overcoming it. Considering the cases of domestic violence can be happened in all society, hence, the nearest institution with the society is the local institution where that society resides in. This institution can be in the form of custom institution. Therefore, it can be one of the alternatives in overcoming cases of domestic violence.
\end{abstract}

Kata Kunci: kekerasan, penanggulangan, institusi lokal, pendekatan kultural

\section{PENDAHULUAN}

Kekerasan Dalam Rumah Tangga (KDRT) menjadi isu penting dalam beberapa dekade terakhir ini, dilatarbelakangi oleh semakin meningkatnya kasus 
KDRT di dunia dan buruknya efek yang ditimbulkan terhadap perempuan dan anak-anak. Menurut laporan World Health Organization (WHO), antara 40 hingga 70 persen perempuan di dunia meninggal akibat kekerasan yang terjadi dalam rumah tangga.

${ }^{1}$ Kenyataan miris tersebut sesungguhnya sangat bertentangan dengan ajaran agama dan moral manapun di dunia ini.

Sehubungan dengan besarnya efek buruk KDRT terhadap perempuan, PBB mendefinisikan KDRT dalam bingkai gender, di mana kekerasan yang dilakukan di dalam lingkup rumah tangga dengan target utama adalah perempuan dan anak-anak ${ }^{2}$. Artinya, KDRT tidak dapat ditolerir dan diabaikan begitu saja. Kasus ini perlu diselesaikan, pertama melalui kekuatan undangundang, kedua pendekatan hukum, ketiga pendekatan ekonomi, dan keempat pendekatan tradisi atau adat. Permasalahan KDRT tidak dapat lagi dianggap sebagai wilayah privat dan urusan rumah tangga belaka, tetapi sudah semestinya dilakukan penyelesaian dengan lintas negara, agama, adat dan disiplin ilmu.

\section{PEMBAHASAN}

\section{Realitas KDRT di Indonesia}

Di Indonesia KDRT juga telah menjadi satu permasalahan yang krusial. Dari tahun ke tahun jumlah korban KDRT selalu meningkat. LBH APIK mencatat ada tiga bentuk kasus KDRT yang selalu meningkat, yaitu kasus kekerasan fisik, psikis, ekonomi dan seksual. Hal ini sangat terlihat pada rentang tahun 1998-2002 (Tabel 1). Sementara untuk tahun 2003 LBH APIK Jakarta menerima pengaduan kasus KDRT sebanyak 280 kasus dengan rincian sebagai berikut, 70 korban kekerasan fisik, 124 korban kekerasan psikis, 85 korban kekerasan ekonomi dan korban kekerasan seksual. ${ }^{3}$ Hal tersebut menunjukkan masalah KDRT di Indonesia sudah menjadi masalah-masalah yang riskan dan kursial. Sementara berdasarkan kasus yang ditangani oleh LBH APIK berdasarkan pengaduan antara tahun 2008 dan 2009, kasus KDRT merupakan kasus yang paling banyak ditangani oleh lembaga ini. Pada tahun 2008 LBH APIK menangani kasus KDRT sebanyak 254 kasus dan pada tahun 2009 sebanyak 657 kasus. Tabel berikut ini menunjukkan jenis kasus KDRT yang pernah dibuat klasifikasinya berdasarkan jenis kekerasan dan ditangani oleh LBH APIK antara tahun 1998-2002.

Tabel 1

Jenis Kasus KDRT yang di Tangani oleh LBH APIK Berdasarkan Klasifikasi Jenis Kasus Antara Tahun 1998-2002 


\begin{tabular}{lccccc}
\hline Jenis Kasus & $\mathbf{1 9 9 8}$ & $\mathbf{1 9 9 9}$ & $\mathbf{2 0 0 0}$ & $\mathbf{2 0 0 1}$ & $\mathbf{2 0 0 2}$ \\
Kekerasan Fisik & 33 & 52 & 69 & 82 & 86 \\
Kekerasan Psikis & 119 & 122 & 174 & 76 & 250 \\
Kekerasan Ekonomi & 58 & 58 & 85 & 16 & 135 \\
Kekerasan Seksual & 3 & 15 & 1 & 0 & 7 \\
Perkosaan & 1 & 10 & 0 & 0 & 0 \\
Pelecehan Seksual & 2 & 5 & 1 & 0 & 0 \\
Ingkar Janji & 0 & 0 & 3 & 14 & 5 \\
Dating Violence & 0 & 0 & 0 & 0 & 7 \\
Penganiayaan Anak & 0 & 0 & 0 & 0 & 1 \\
\hline
\end{tabular}

Sumber: Laporan Penelitian LBH APIK Jakarta Tahun 1998-2002

Korban KDRT yang selalu meningkat ini telah mendorong lahirnya Undang-Undang No. 23 tahun 2004, sehingga dengan Undang-undang tersebut, ada kekuatan hukum yang mengatur masalah kasus KDRT di Indonesia, sekaligus sebagai salah satu upaya untuk mengatasi permasalahan KDRT di Indonesia.

Namun, setelah keluarnya undang-undang tersebut, jumlah kasus KDRT masih mengalami peningkatan di Indonesia. Hal ini dapat diartikan bahwa pelaksanaan Undang-Undang KDRT belum berhasil menekan dan menyelesaikan masalah ini. Kasus tersebut tidak lagi menjadi kasus sekelompok masyarakat, tetapi juga telah menjadi fenomena di pedesaan dan juga di perkotaan ${ }^{4}$.

Peningkatan kasus KDRT pasca undang-undang itu dapat dilihat dari hasil yang dilaporkan oleh Kantor Menteri Pemberdayaan Perempuan. Selama tahun 2007 telah terjadi kasus KDRT sebanyak 22 ribu, jumlah ini meningkat lima kali lipat jika dibandingkan dengan tahun sebelumnya ${ }^{5}$. Komnas Perempuan mencatat kasus KDRT yang terjadi dari tahun 2005-2009, dengan sasaran korban adalah perempuan. Artinya kekerasan terhadap perempuan di Indonesia selalu meningkat dan kekerasan tersebut merupakan bahagian yang tidak terpisahkan dari kasus-kasus KDRT, tabel berikut ini menjelaskan peningkatan-peningkatan itu:

Tabel 2

Jumlah Kasus KDRT di Indonesia dari Tahun 2005-2009

\begin{tabular}{|l|c|c|c|c|c|}
\hline Tahun & 2005 & 2006 & 2007 & 2008 & 2009 \\
\hline Jumlah Kasus & 20.391 & 22.512 & 25.522 & 54.425 & 143.586 \\
\hline
\end{tabular}

Sumber: $\quad$ http://www.komnasperempuan.or.id/wp-content/ uploads/2010/03/Laporan-Hasil-KerjaKomisi-Nasional-Anti-Kekerasan-terhadap-Perempuan-Periode-2004-2009.pdf 
Dari tabel di atas dapat ditangkap bahwa kasus KDRT selalu meningkat pasca lahirnya Undang-Undang KDRT. Peningkatan jumlah tersebut cukup signifikan. Pada tahun 2005 hanya tercatat sebanyak 20.391 kasus, tahun 2006, 22.512 kasus dan 2007 meningkat menjadi 25.522 kasus dan pada tahun 2008 meningkat secara drastis dua kali lipat menjadi 54.425 kasus. Sedangkan pada tahun 2009 drastis naik menjadi tiga kali lipat yakni 143.586 kasus.

Peningkatan jumlah kasus KDRT tersebut dilatarbelakangi oleh berbagai faktor, mulai dari faktor budaya, ideologi, sampai pada kesadaran masyarakat yang masih rendah terhadap permasalahan KDRT, bahkan KDRT masih dianggap sebagai permasalahan biasa dalam rumah tangga ${ }^{6}$. Hal yang tidak kalah penting, masalah ekonomi juga menjadi pemicu yang signifikan terhadap kasus KDRT ini. Bahkan jika dilihat dari perspektif kultural, terutama berdasarkan kultur kekerabatan, bahwa kekerasan dalam rumah tangga secara signifikan tidak berpengaruh terhadap tidak berlakunya kasus tersebut. Hal ini dapat dilhat dari sosiokultural matrilinial di Sumatera Barat. Di mana korban KDRT juga mengalami peningkatan yang signifikan. Pada tahun 2003 korban kasus KDRT berjumlah 132 kasus, kemudian tahun 2004 sebanyak 174 kasus, tahun 2005 menjadi 287 kasus dan tahun 2006 tercatat sebanyak 286 kasus 7 . Jika dibandingkan antara tahun 2006 dengan tahun 2005, kasus KDRT di Sumatera Barat hanya turun satu kasus saja. Artinya, kasus KDRT masih menjadi permasalahan di daerah yang menganut sistem kekerabatan matrilineal ini.

Dalam tahun 2007, kasus KDRT di Sumatera Barat mengalami peningkatan, kasus ini lebih banyak dipicu oleh kesadaran masyarakat yang masih rendah, ideologi dan budaya setempat serta faktor ekonomi. Hal ini sejalan dengan pendapat Erlangga Masdiana yang menyatakan meningkatnya kasus KDRT sangat dipengaruhi oleh ideologi dan pemahaman budaya masyarakat. ${ }^{8}$

Ideologi dan budaya masih merekonstruksi dengan menempatkan permasalahan KDRT sebagai masalah domestik, sehingga kasus KDRT dianggap permasalahan keluarga yang biasa. Akhirnya kasus tersebut tidak dilaporkan atau tidak menjadi perhatian dari masyarakat setempat. Kasus KDRT akhirnya dianggap sebagai permasalahan biasa dalam masyarakat.

Pencitraan kasus KDRT yang demikian itu, menjadi salah satu penyebab kasus-kasus KDRT tidak dapat diatasi secara cepat, akhirnya secara langsung atau tidak langsung kasus tersebut selalu mengalami peningkatan jumlahnya. Oleh sebab itu, dalam mencermati permasalahan kasus KDRT harus dilakukan dengan berbagai pendekatan kultural, tidak hanya bisa dilakukan dengan pendekatan-pendekatan hukum formal.

Selain dari faktor ideologi dan budaya, faktor ekonomi ternyata mempengaruhi meningkatnya korban KDRT di Indonesia, sehingga tingginya 
angka kemiskinan diikuti pula oleh kasus KDRT yang tinggi ${ }^{9}$. Oleh sebab itu, tidak mengherankan pada tahun 2007 angka KDRT meningkat lima kali lipat jika dibandingkan dengan tahun 2006, karena angka kemiskinan dalam tahun 2006 jauh mengalami peningkatan yang tajam pada tahun 200710. Asumsi ini berlaku dalam memprediksikan jumlah kasus KDRT pada tahun selanjutnya. Masalahnya, jumlah kemiskinan yang belum teratasi sampai tahun ini, bahkan sampai Maret 2010 ini, angka kemiskinan di Indonesia masih berada di atas angka 30 juta jiwa. Badan Pusat Statistik mencatat angka kemiskinan di Indonesia saat ini mencapai 31,2 juta jiwa.

Indikasinya terhadap kasus-kasus KDRT adalah, bahwa angka kemiskinan yang tinggi juga akan mempengaruhi terhadap peningkatan kasus KDRT di Indonesia. Hal ini sejalan dengan tesis Marx yang menempatkan kesejahteraan atau penguasaan ekonomi sangat berpengaruh pada dinamika sosial masyarakat. Dalam konteks ini, juga terlihat dari kasus-kasus perceraian, bahwa angka penceraian yang tinggi pada satu kawasan lebih dominan disebabkan oleh faktor ekonomi tersebut.

Di samping diakibatkan oleh ideologi, budaya, dan ekonomi, kasus KDRT yang meningkat juga dipengaruhi oleh minimnya lembaga dan sarana untuk menanggulangi kasus KDRT tersebut. Hal ini terlihat dari jumlah ruang khusus yang ada di kepolisian tidak seimbang dengan rasio jumlah penduduk Indonesia.

Lembaga yang minim ini tidak dapat mengakses kasus KDRT secara optimal dan bahkan hanya terakses jika ada yang melaporkan saja, itu pun harus melapor dengan data yang lengkap. Sementara masyarakat Indonesia belum sepenuhnya mempunyai kesadaran untuk melaporkan kasus ini pada pihak yang berwajib dan masih menganggap kasus KDRT sebagai kasus biasa. Keterbatasan jumlah lembaga tersebut sebagai salah satu faktor belum berhasilnya pengentasan masalah KDRT di Indonesia.

\section{Upaya Pencegahan}

Kasus KDRT yang selalu meningkat ini diperlukan usaha dan upaya untuk menanggulanginya, yaitu melalui penguatan peranan institusi lokal, dan penguatan peranan institusi formal.

\section{Penguatan Institusi Lokal}

Selama ini, minimnya jumlah institusi yang menangani masalah KDRT ternyata telah mempengaruhi banyaknya kasus KDRT tidak tertanggulangi sehingga jumlah kasus tersebut selalu mengalami peningkatan. Pemerintah sendiri baru mempunyai 237 unit Ruang Pelayanan Khusus (RPK) di 33 Kepolisian Daerah (Polda) seluruh Indonesia untuk menangani kasus KDRT ini ${ }^{11}$. Jumlah pelayanan tersebut jelas masih sangat sedikit jika dibandingkan dengan 
jumlah penduduk Indonesia yang berjumlah 224 juta jiwa. Sementara kesadaran masyarakat yang masih rendah untuk melaporkan kasus tersebut tentu tidak mendukung efektifnya kinerja unit pelayanan yang ada di kopolisian tersebut. Oleh sebab itu, perlu adanya lembaga-lembaga atau institusi lain yang dapat menanggulangi masalah ini.

Keberadaan institusi lokal sangat diperlukan. Institusi lokal ini akan dapat menyentuh secara lansung masyarakat paling bawah, karena tingginya kasus KDRT di Indonesia tidak terlepas dari minimnya lembaga yang menanggulangi masalah KDRT. Selain itu, lembaga yang ada sangat bersifat formal dan korban pun harus melaporkan permasalahannya secara formal, sedangkan kesadaran masyarakat untuk melaporkan secara formal ini masih rendah. Sehubungan dengan itu, pada era otonomi daerah sekarang sedang terjadi penguatan insitusi lokal, maka institusi lokal tersebut mempunyai peranan penting dalam menanggulangi persoalan kasus KDRT.

Di Sumatera Barat misalnya, penguatan institusi lokal terlihat seiringan dengan terjadinya perubahan sistem pemerintahan desa menjadi sistem pemerintahan nagari yang diatur melalui Perda no 9 tahun 2000. Kembali pada pemerintahan nagari secara langsung mengembalikan pula peranan lembaga adat. Pasal 4 dan 5 dari Perda no. 9 tahun 2000 tersebut secara tegas menyebutkan dalam pemerintahan nagari dibangun kembali lembaga adat dan syarak. Lembaga adat menjadi aset dalam penanggulangan masalah anak kemanakan dalam nagari, karena lembaga adat ini mempunyai tanggungjawab dalam menyelesaikan permasalahan anak-kemenakan yang terjadi dalam nagari.

Jika dilihat data pemerintahan nagari pada pemerintahan Sumatera Barat sampai pada tahun 2008 ini, pemerintahan nagari sudah berjumlah 518 buah nagari di kabupaten dan 62 buah nagari di kota. Ini berarti jumlah lembaga adat yang terbentuk di Sumatera Barat sebanyak jumlah nagari itu pula, yaitu 580 lembaga adat. Jumlah lembaga adat yang begitu banyak ini cukup signifikan dalam mengatasi masalah yang dihadapi oleh penduduk Sumatera Barat yang berjumlah 4.241.256 jiwa orang.

\section{Penguatan Institusi-Institusi Formal}

Pendekatan gender merupakan pendekatan yang sering dipakai dalam menyelesaikan kasus KDRT. Salah satu keuntungan melihat kasus KDRT dengan pendekatan gender ini adalah memberikan ketegasan penyelesaian kasus KDRT melalui jalur hukum. Perspektif ini pula yang dipakai oleh Undang-Undang No 23 tahun 2004, di mana penyelesaian kasus KDRT harus dilakukan dengan penyentuhan hukum dan penyelesaian lembaga-lembaga yang bertanggungjawab. 
Oleh sebab itu diperlukan Ruang Pelayanan Khusus (RPK) di Kepolisian. Artinya, dengan adanya undang-undang KDRT telah lahir satu institusi khusus di kepolisian. Hal ini dianggap sebagai salah satu upaya dalam menyelesaikan kasus KDRT melalui penyelesaian hukum. Penyelesaian kasus KDRT melalui jalur hukum ini sebagai upaya untuk menegakkan hak asasi manusia di Indonesia.

Hasil penelitian Devisi Gender dan Pembangunan Pusat Studi Pertanian dan Pembangunan Pedesaan IPB, yang terpenting dilihat dari penyelesaian kasus KDRT adalah faktor penyebab atau akar persoalan dari KDRT tersebut. Tanpa memperhatikan akar persoalan itu, kasus KDRT sulit untuk diselesaikan. Meningkatnya kasus KDRT di Indonesia akhir-akhir ini, diakibatkan oleh, salah satunya, penyelesaian kasus KDRT yang tidak menyentuh akar persoalan. Salah satu alternatif yang perlu dilakukan untuk penyelesaian dan penanggulangan KDRT adalah memperkuat pengembangan kelompok sosial. Kelompok sosial ini berupa lembaga-lembaga yang dapat mengontrol dan mengawasi terjadinya permasalahan KDRT tersebut.

Penelitian yang dilakukan oleh kelompok Institusi Perempuan, menemukan ketidakberhasilan penanganan KDRT ternyata diakibatkan oleh minimnya kasus ini terekspos ke permukaan, sehingga kasus KDRT dianggap kasus biasa. Hal ini terbukti dari 146 kasus yang ditemukan oleh Institusi Perempuan, hanya 16 kasus yang teridentifikasi pola penanganannya melalui jalur hukum ${ }^{12}$. Hal ini berarti rendahnya kesadaran masyarakat terhadap kasus KDRT yang menyebabkan semakin meningkatkan jumlah kasus tersebut.

Kesadaran masyarakat yang rendah melaporkan kasus KDRT dipengaruhi oleh berbagai faktor, pertama ideologi. Di kalangan masyarakat Indonesia masalah rumah tangga telah direkonstruksi oleh budaya sebagai masalah pribadi atau masalah domestik, sehingga masalah ini dianggap tidak layak diselesaikan di luar rumah tangga. Di samping itu, korban KDRT pada umumnya anak-anak dan perempuan maka kasus ini sering tidak dilaporkan oleh pihak korban kepada pihak yang berwajib. Kedua, masih kuatnya superioritas laki-laki dalam rumah tangga di mana laki-laki sebagai kepala rumah tangga, kekuatan ekonomi keluarga dan sebagainya maka melaporkan kekerasaan yang dilakukan oleh laki-laki dianggap sebagai suatu ancaman terhadap keluarga, maka korban lebih memilih diam dan menerima kekerasaan tersebut, seperti kasus suami membentak istri, suami main serong, suami tidak memberikan uang belanja cenderung dianggap hal yang biasa dilakukan oleh suami, pada hal tindakan tersebut sudah termasuk kasus KDRT. ${ }^{13}$

Di samping itu, sulitnya kasus KDRT diakses oleh penegak hukum dan tidak berimbangnya rasio jumlah ruangan khusus penanganan KDRT di 
Indonesia merupakan hal yang menyebabkan kasus tersebut dianggap sebagai kasus yang biasa dan tidak banyak diperhatikan oleh masyarakat ${ }^{14}$.

Kekerasan dalam rumah tangga atau domestic violence adalah kekerasan yang terjadi dalam lingkup rumah tangga. Sedangkan ruang lingkup rumah tangga yang dimaksud oleh Undang-Undang No. 23 tahun 2004 adalah (a) pasangan atau mantan pasangan di dalam maupun di luar perkawinan.(b) Orang-orang yang mempunyai hubungan keluarga karena darah, perkawinan, adopsi, dan hubungan adat dan atau agama. (c) orang yang bekerja membantu kehidupan rumah tangga orang lain yang menetap atau tidak di sebuah rumah tangga. (d) orang yang masih tinggal dan atau pernah tinggal bersama

Home Affairs Select Committee (HASC) mendefinisikan KDRT sebagai : "semua bentuk penganiayaan fisik, seksual atau emosional yang berlangsung dalam konteks suatu hubungan yang erat. Dalam banyak kasus, hubungan yang terjadi di antara pasangan (yang dinikahi, kumpul kebo, dan yang lainnya) atau bekas pasangan."

Hukum di Amerika Serikat mendefinisikan KDRT sebagai bentuk penganiayaan yang dilakukan terhadap pasangan atau mantan pasangan, pasangan kumpul kebo, baik yang sekarang maupun dahulu, atau hubungan kencan ataupun hubungan pertunangan. Kepolisian Inggris (1999) mendefinisikan KDRT dengan semua kekerasan antar pasangan dalam suatu hubungan intim, baik yang telah lewat atau sekarang. Kekerasan yang terjadi meliputi penganiayaan fisik, seksual, emosional dan finansial.

Korban dari KDRT dapat berupa laki-laki, perempuan, dan anak-anak. Hasil penelitian Universitas Manitoba Sandy Hershcovis dan peneliti Universitas Queen Julian Barling mempublikasikan data bahwa kekerasan lebih dominan dilakukan oleh laki-laki dan korbannya lebih dominan perempuan dan anakanak $^{15}$. Hal ini disebabkan pertama perempuan dan anak-anak selalu di bawah lindungan laki-laki, sehingga mereka sering menjadi korban emosi laki-laki. Hal ini dapat dilihat dari analisis Sally E. Merry, kekerasan adalah suatu tanda dari perjuangan untuk memelihara beberapa fantasi dari identitas dan kekuasaan. Dalam konteks ini kekerasan yang dilakukan laki-laki sebagai emosional dari superioritasnya ${ }^{16}$.

Banyaknya jumlah kasus KDRT yang terjadi di dunia telah menjadikan kasus ini berada dalam ruang lingkup HAM internasional. Hal ini dapat dilihat dalam dokumen HAM internasional yang meliputi tindakan untuk memukul perempuan, misalnya, telah dimasukkan di dalam konvensi HAM internasional maupun regional yang mempunyai sifat hukum mengikat terhadap negara yang telah meratifikasinya. Dokumen HAM Internasional tersebut meliputi, Universal Declaration of Human Rights (UDHR), the International Covenant on Civil and Political Rights (ICCPR), dan the International Covenant on Economic, Social and 
Cultural Rights (ICESCR). Dokumen ini menjadi standar umum sehingga korban dari KDRT dapat menggugat negaranya masing-masing.

Di Indonesia, penyelesaian kasus KDRT telah diatur oleh UndangUndang No. 23 tahun 2004. Undang-undang ini mendefinisikan KDRT sebagai setiap perbuatan terhadap seseorang terutama terhadap perempuan, yang berakibat timbulnya kesengsaraan atau penderitaan secara fisik, seksual, psikologis, dan/atau penelantaran rumah tangga termasuk ancaman untuk melakukan perbuatan, pemaksaan, atau perampasan kemerdekaan secara melawan hukum dalam lingkup rumah tangga.

Ruang lingkup rumah tangga menurut undang-undang ini adalah: 1)Suami, isteri, dan anak (termasuk anak angkat dan anak tiri), 2)Orang-orang yang mempunyai hubungan keluarga dengan orang sebagaimana dimaksud dalam huruf $a$ karena hubungan darah, perkawinan, persusuan, pengasuhan, dan perwalian, yang menetap dalam rumah tangga (mertua, menantu, ipar dan besan); dan/atau 3) Orang yang bekerja membantu rumah tangga dan menetap dalam rumah tangga tersebut (Pekerja Rumah Tangga) ${ }^{17}$.

Selanjutnya undang-undang menjelaskan secara rinci tentang bentukbentuk kekerasan dalam rumah tangga, yaitu: 1) Kekerasan fisik; yaitu perbuatan yang mengakibatkan rasa sakit, jatuh sakit atau luka berat (Pasal 6), 2)Kekerasan psikis; yaitu perbuatan yang mengakibatkan ketakutan, hilangnya rasa percaya diri, hilangnya kemampuan untuk bertindak, rasa tidak berdaya, dan/atau penderitaan psikis berat pada seseorang (pasal 7), 3) Kekerasan seksual; yaitu setiap perbuatan yang berupa pemaksaan hubungan seksual, pemaksaan hubungan seksual dengan cara tidak wajar dan/atau tidak disukai, pemaksaan hubungan seksual dengan orang lain untuk tujuan komersial dan/atau tujuan tertentu. Kekerasan seksual ini meliputi: (pasal 8) a) Pemaksaan hubungan seksual yang dilakukan terhadap orang yang menetap dalam lingkup rumah tangga tersebut; b) Pemaksaan hubungan seksual terhadap salah seorang dalam lingkup rumah tangganya dengan orang lain untuk tujuan komersial dan/atau tujuan tertentu. 4) Penelantaran rumah tangga; yaitu seseorang yang menelantarkan orang dalam lingkup rumah tangganya, padahal menurut hukum yang berlaku baginya atau karena persetujuan atau perjanjian ia wajib memberikan kehidupan, perawatan, atau pemeliharaan kepada orang tersebut. Selain itu, penelantaran juga berlaku bagi setiap orang yang mengakibatkan ketergantungan ekonomi dengan cara membatasi dan/atau melarang untuk bekerja yang layak di dalam atau di luar rumah sehingga korban berada di bawah kendali orang tersebut (pasal 9).

Pengertian KDRT dalam penelitian ini, tertakluk pada pengertian yang dirumuskan oleh undang-undang No. 23 tahun 2004 tersebut. Undang-undang ini, telah mendefinisikan secara jelas tentang KDRT dan telah melahirkan 
perspektif dan penyelesaian KDRT. Tetapi perspektif tersebut, belum sepenuhnya dapat diterima dan difahami oleh masyarakat, sehingga kasus KDRT masih dianggap sebagai kasus domestik dan tidak layak dipublikasikan. Hal ini yang menyebabkan sulitnya mengungkap kasus KDRT di tengah-tengah masyarakat Indonesia.

Hasil penelitian yang dilakukan oleh Institusi Perempuan menunjukkan, selama bulan Januari sampai Juni 2007 dari 149 kasus yang ditelaah dari 20 kabupaten di Pulau Jawa 60\% dari kasus tersebut merupakan korban KDRT. Dari $60 \%$ tersebut 16 meninggal akibat KDRT. Sementara menurut Rimiyanti Aziz, jumlah tersebut melebihi dari kasus yang dilaporkan, karena kasus tersebut sering ditutupi dan tidak banyak dilaporkan. Kasus yang sama pun terjadi di Sumatera Barat, sehingga kasus ini sedikit dapat ditangani oleh pihakpihak yang bertanggungjawab ${ }^{18}$.

Perspektif dan kesadaran masyarakat yang rendah telah mengakibatkan kasus KDRT tidak banyak terungkap ke permukaan. Pada hal kasus KDRT sudah banyak menelan korban, baik korban jiwa maupun fisik dan psikis. Hasil penelitian Devisi Gender dan Pembangunan Pusat Studi Pembangunan dan Pedesaan IPB menunjukkan KDRT yang terjadi di Indonesia selama ini telah berdampak terhadap ketidakberdayaan perempuan dan anak-anak, karena pada umumnya yang menjadi korban dari KDRT adalah perempuan dan anak-anak ${ }^{19}$.

Menurut Rubin dan Rubin, akibat rendahnya kesadaran masyarakat tersebut, kasus KDRT sering tidak mendapat penyelesaian, sehingga korban pun malas melaporkan masalahnya. Lebih lanjut, Rubin dan Rubin menjelaskan seseorang merasa tidak berdaya karena sendirian menghadapi persoalan itu, oleh sebab itu untuk menyelesaikan masalah diperlukan pengorganisasian atau kelompok sosial ${ }^{20}$.

Kelompok sosial yang mewadahi pemberdayaan itu yang belum banyak ditemukan dalam mengatasi masalah KDRT. Dalam konteks ini, wadah-wadah yang mempunyai perspektif yang sama dalam organisasi sosial tersebut yang efisien dalam menanggulangi suatu masalah.

Penangulangan masalah KDRT yang tertumpu pada Undang-Undang No. 23 tahun 2004 saja tidak cukup dan diperlukan perspektif dan upaya-upaya lokal yang signifikan. Masalahnya KDRT dalam masyarakat Indonesia masih belum diterima sebagai sebuah masalah publik, tetapi masih berada dalam masalah domestik, rahasia rumah tangga. Oleh sebab itu untuk menghadapi permasalahan KDRT di Indonesia masih perlu dilakukan dengan pendekatan lokal, sehingga lokal mempunyai peranan penting dalam menyelesaikan permasalahan-permasalahan sekitarnya ${ }^{21}$.

Dalam konteks ini pula, organisasi dan birokrasi perlu menangani permasalahan masyarakat. Weber menjelaskan birokrasi sebagai sebuah sarana 
untuk mengatur kehidupan sosial masyarakat. Hal ini pun dipertegas oleh penganut struktural seperti Parsons, yang menyatakan institusi sebagai sistem yang dapat mengarahkan tindakan masyarakat ${ }^{22}$.

\section{SIMPULAN}

Di Indonesia, penanggulangan kasus KDRT telah dilakukan dengan serius oleh pemerintah, salah satunya ditandai dengan lahirnya undang-undang no 23 tahun 2004. Undang-undang ini menjadi dasar hukum untuk menyelesaikan kasus KDRT. Undang-Undang ini juga menyebutkan bahwa setiap orang yang mendengar, melihat, atau mengetahui terjadinya kekerasan dalam rumah tangga wajib melakukan upaya-upaya sesuai dengan batas kemampuannya (pasal 15): Hal ini tujuannya sangat jelas, diantaranya yaitu: a. Mencegah berlangsungnya tindak pidana; b. Memberikan perlindungan kepada korban; c. Memberikan pertolongan darurat; d. Membantu proses pengajuan permohonan penetapan perlindungan.

Namun untuk kejahatan kekerasan psikis dan fisik ringan serta kekerasan seksual yang terjadi dalam relasi antar suami istri, maka yang berlaku adalah delik aduan. Maksudnya korban sendiri yang melaporkan secara langsung kekerasan dalam rumah tangga kepada kepolisian (pasal 26 ayat 1). Namun korban dapat memberikan kuasa kepada keluarga atau orang lain untuk melaporkan kekerasan dalam rumah tangga kepada pihak kepolisian (pasal 26 ayat 2). Dalam hal korban adalah seorang anak, laporan dapat dilakukan oleh orang tua, wali, pengasuh atau anak yang bersangkutan (pasal 27). Untuk mengoptimalkan pelaksanaan dari undang-undang ini dibentuk ruangan khusus di setiap kepolisan daerah provinsi.

Di samping akibat masalah KDRT yang masih dianggap sebagai permasalahan yang biasa dan domestik oleh masyarakat Indonesia, maka upayaupaya pencegahan supaya kasus ini tidak meluas sangat diperlukan dengan pendekatan-pendekatan kultural juga, salah satunya harus dilakukan dengan pendekatan institusi lokal, karena institusi lokal dianggap institusi yang dekat dengan masyarakat lapisan paling asas. Pendekatan seperti ini, sangat berfungsi untuk mengatasi kasus-kasus KDRT yang bergelinding di dalam masyarakat awam.

\section{Endnotes:}

1 World Health Organization, World Report on Violence and Health 93 (2002), dapat diakses melalui www.who.int/violence_injury_prevention/violence/world_report/en/.

2 Report of the Special Rapporteur on Violence Against Women, Its Causes and Consequences, Ms. Radhika Coomaraswamy, disampaikan kepada Commission on Human Rights Resolution 1995/85, a Framework for Model Legislation on Domestic Violence, U.N. ESCOR, 
Comm'n on Hum. Rts., 52d Sess., Agenda Item 9(a), addendum, 28, U.N. Doc. E/CN.4/1996/53/Add. 2 (1996).

3 LBH-APIK (2003). Gugatan atasa Peran Negara yang Mendua : Upaya Menuju Otonomisasi Perempuan. Catatan refleksi tahun 2003. diakses dari website www. Lbh-appik.or.id_pada tanggal 9 Juni 2004

$4 \quad$ http://www.kompascetak.com/kompas-cetak/0710/25/sumbagsel/3940765.htm. 25 Oktober 2007. Korban KDRT jumlah selalu meningkat dan keberadaan undang-undang no 23 tahun 2004 harus disosialisasikan dan korban KDRT mesti mendapat pendampingan. Kesadaran masyarakat terhadap kasus ini masih rendah dan lebaga institusi adat belum mempunyai kepedulian dalam masalah ini.

5 Lihat laporan kantor Menteri Pemberdayaan Perempuan yang dimuat oleh suara karta online: http://www.suarakarya-online.com/news.html?id=173103. 15 Mei 2007

6 http://www.institusiperempuan.org.id/statistik kerasan terhadap peremuan.htm.Banyaknya kasus KDRT yang tidak dilaporkan ke pihak yang bertanggungjawab, salah satunya diakibatkan oleh kesadaran masyarakat yang masih rendah terhadap hal ini. Kasus KDRT masih dianggap sebagai kasus domestik yang tidak mangkus dipublikasikan. Hal ini menjadi salah satu penyebab tidak tersentuhnya penyelesaian kasus KDRT di Indonesia.

7 Laporan pemberdayaan perempuan Sumatera Barat.

8 www.kompas.com; korban KDRT selalu meningkat. Erlangga Masdiana pemerhati perempuan dan dosen UI.

9 Komnas Perempuan, melaporkan kemiskinan secara signifikan mempengaruhi meningkatnya kasus KDRT, dari data tahun 2005 sampai 2007, dari kasus yang dilaporkan penyebab yang lebih dominan dari KDRT adalah faktor ekonomi rumah tangga.

10 Menurut laporan BPS, pada tahun 2006 terdapat masyarakat miskin di Indonesia sebanyak 10,4\% dan pada tahun 2007 meningkat menjadi 37,9\%.

11 Laporan Kantor Menteri Pemberdayaan Perempuan. Lihat juga hasi penelitian yang dilakukan oleh kelompok peneliti UNPAD, tentang Efektivitas Pelayanan Ruang Khusus Kepolisian Dalam Implementasi Undang-Undang No 23 Tahun 2004 Tentang KDRT. Penelitian ini merekomendasikan, bahwa pelayanan ruang khusus yang ada di kepolisian untuk dapat menanggani kasus KDRT secara efektif dan diperlukan ehadiran lembaga atau institusi lain yang dapat bekerjasama untuk mengtasi kasus KDRT ini.

12 Hasil penelitian Institusi Perempuan tahun 2006

13 Kollman, Nathalie. Kekerasan terhadap Perempuan. Jakarta: YLKI dan Ford Foundation, 1998.

14 Antik Bintari, dkk. Efektivita Pelayanan Ruang Pelayanan Khusus Kepolisian Dalam Implementasi Undang-Undang NO 23 TAHUN 2004. Bandung: Unpad

15 www. koran SINDO, Satu Koran Segala Berita-Kekerasan Kerja Turunkan Produktivitas.mht: 15 Maret 2008.

16 Sally E. Merry, Rights Talk and the Experience of Law: Implementing Women's Human Rights to Protection from Violence, 25 HUM. RTS. Q. 343, 350, 2003

17 Lihat pasal 1 ayat 1 dan 2 dari Undang-Undang No 23 Tahun 2004 tersebut.

18 Lihat usaha yang dilakukan oleh P2TP2A Kabupaten S Sijunjung hanya berhasil menangani kasus KDRT sebanyak 17 kasus, pada hal kasus ini lebih banyak dari yang dilaporkan ini.

19 Hasil penelitian yang dilakukan oleh devis gender dan pembangunan. Pusat Studi Pembangunan dan Pedesaan IBP.

20 Rubin, Herbet, J \& Irene, Irene S. 2001. Community Organizing dan Development. Allyn and Bocan. 
21 Pendekatan lokal ini, sudah lama diajukan oleh Parson dan kemudian dalam psot kolonial disuarakan kembali. Bahwa dalam penyelesaian masalah duni ke tiga atau yang sedang membangun tidak semestinya dengan cara adopsi tata cara luar, lebih tepat duselesaikan dengan pendekatan yang ada dalam masyarakat tersebut.

22 Parsons, Weber dalam Ritzer dan Goodman. 2004. Teori Sosiologi Modern. Jakarta: Kencana.

\section{DAFTAR PUSTAKA}

Antik Bintari, Neneng Yani Yuningsih, Iman Soleh, Muradi. 2007. Efektivita Pelayanan Ruang Pelayanan Khusus Kepolisian Dalam Implementasi Undang-Undang NO 23 TAHUN 2004. Bandung: Unpad.

Blac, A. James. 1999. Metode dan Masalah Penelitian Sosial. Bandung: Refika Aditama

Bungin. 2001. Metode dan Masalah Penelitian Sosial. Bandung: Transito.

Erlangga Masdiana. 2007. Korban KDRT Meningkat. www.kompascetak.com

Freeman, M.D.A. 1980. Violence in the home. England: Gower Publishing Company Limited.

Friedmann, John. 1991. Empowerment: The Politic Alternative Development. Massachusett: Blackwell Publizher.

Frieze, I.H. 2005. Hunting the one you love: violence in relationships. USA: Wadswoth.

Illich, Ivan. 2002. Perayaan Kesadaran Sebuah Panggilan untuk Revolusi Institusi. Yogyakarta: Ikon Teralitera.

Jacobson, N\&Gottman, J. 2004. Basic Fact About Batting: Myths vs reality. Dlm. Coltrane, S. Families and siciety: Classic and contemporary reading. Canada: Wadsworth.

LBH-APIK. 2003. Gugatan atasa Peran Negara yang Mendua : Upaya Menuju Otonomisasi Perempuan. Catatan refleksi tahun 2003. diakses dari website_www. Lbh-appik.or.id_pada tanggal 9 Juni 2004

Lembaga Kerapatan Adat Alam Minangkabau. 2000. Bunga Rampai Pengetahuan Adat Minangkabau. Padang: LKAAM. 
M. Noe. Peranan Ninik Mamak Kembali Pada Pemerintahah Nagari. Bunga Rampai Pengetahuan Adat Minangkabau. 2000. Padang: LKAAM.

Menteri Pemberdayaan Perempuan. 2007. http:/www.suarakaryaonline.com.

Muhadjir, Neong. 1996. Metode Penelitian Kualitatif. Yogyakarta: Rake Sharasin.

Perda no 9 tahun 2000. Tentang Pemerintahan Nagari.

Prasetyo, Bambang. 2005. Metode Penelitian Kuantitatif Teori dan Aplikasi. Jakarta: Raja Grafindo Prasada.

Report of the Special Rapporteur on Violence Against Women, Its Causes and Consequences, Ms. Radhika Coomaraswamy. Disampaikan kepada Commission on Human Rights Resolution 1995/85, a Framework for Model Legislation on Domestic Violence, U.N. ESCOR, Comm'n on Hum. Rts., 1996. 52d Sess., Agenda Item 9(a), addendum, 28. U.N. Doc. E/CN.4/1996/53/Add. 2.

Rubin, Herbet, J \& Irene, Irene S. 2001. Community Organizing dan Development. Allyn and Bocan.

Saunders, D.G. 1995. The tendency to arrest victims of domestic vilonece. Journal of interpersonal violence.

Sally E. Merry. 2003. Rights Talk and the Experience of Law: Implementing Women's Human Rights to Protection from Violence, 25 HUM. RTS.

Strong, B\& Devault. 1992. The Marriage and Family experience. USA: West Publishing Company.

Undang-Undang No 23 tahun 2004.

Wacjman, Judi. 2001. Feminisme Versus Teknolog. Yogyakarta: Sekretariat Bersama Perempuan Yogyakarta.

Weber, M. 1974. On charisma and institution building. Chicago: Chicago University Press.

World Health Organization, World Report on Violence and Health 93 (2002)www.who.int/violence_injury_prevention/violence/world_r eport/en/ 
http://www.komnasperempuan.or.id/wpcontent/uploads/2010/03/Lap oran-Hasil-Kerja-Komisi-Nasional-Anti-Kekerasan-terhadap Perempuan-Periode-2004-2009.pdf

Yuhong Zhao. 1986. Domestic Violence in China: In Search of Legal and Social Responses, 18 UCLA PAC. BASIN L.J. 